\title{
Acute cerebellar ataxia and infectious mononucleosis
}

\author{
N. K. WADHWA* \\ M.D., M.R.C.P. (UK), M.R.C.P. (I)
}

R. R. GHOSE

F.R.C.P. (Lond), F.R.C.P. (Edin)

\author{
Singleton Hospital, Sketty, Swansea SA2 8QA
}

\begin{abstract}
Summary
A 28-year-old man, who presented with acute cerebellar ataxia, was found to have haematological features of infectious mononucleosis. There was serological evidence of recent infection with Epstein-Barr virus. It is speculated that cerebellar dysfunction results from virus-induced inflammatory changes within the central nervous system.
\end{abstract}

KEY WORDS: cerebellar ataxia, infectious mononucleosis.

\section{Introduction}

Acute cerebellar ataxia complicating infectious mononucleosis was first reported in 1941, and 13 cases have subsequently been documented (Dowling and Vanslyck, 1966; Cleary, Henle and Pickering, 1980). Prognosis is good, whether corticosteroids are given or not, and complete recovery occurs after 1-4 months. Males are predominantly affected. The presentation is exceptionally rare in adults (Lascelles, et al., 1973; Bajada 1976), and a further case is recorded.

\section{Case report}

A 28-year-old man was admitted with a 3 week history of occipital headache; progressive clumsiness, with difficulty in walking and slurring of speech. For 2 days before admission, moderate pyrexia was present and he complained of nausea and vomiting. There was no history of sore throat or rash.

Physical examination revealed a temperature of $38.2^{\circ} \mathrm{C}$. Blood pressure was $130 / 80 \mathrm{mmHg}$. There was minimal cervical lymphadenopathy. The pharynx and fauces were normal. There was no hepatosplenomegaly. Neurological examination showed an alert, well-orientated man. Cranial nerves and optic fundi were normal. There was no nystagmus or dysarthria. Sensation and power were normal. Deep tendon reflexes were markedly diminished. He had bilateral disturbance of finger-nose and heel-shin

*Present address: South Cleveland Hospital, Middlesbrough TS4 3BW. testing; symmetrical hypotonia and decreased motor co-ordination with truncal ataxia.

Investigations showed a haemoglobin of $14.0 \mathrm{~g} / \mathrm{dl}$; white cell count $3.9 \times 10^{9} /$ litre (neutrophils $64 \%$, atypical lymphocytes $30 \%$ and monocytes $6 \%$ ). Cerebrospinal fluid (CSF) revealed 1-2 lymphocytes per cubic millimetre; protein level $0.3 \mathrm{~g} /$ litre and glucose level $4 \cdot 1 \mathrm{mmol} /$ litre. Blood and cerebrospinal fluid for bacterial culture were sterile. Chest X-ray, skull $\mathrm{X}$-rays and computerized tomographic scan were normal. Electroencephalogram revealed a slightly abnormal record with diffuse slower frequencies. Plasma urea, electrolytes, glucose, calcium, proteins and liver function tests were normal. The Paul Bunnell test (serum heterophilic antibodies titre) and serum IgG and IgM antibodies against Epstein-Barr virus (EBV) capsid are shown in Table 1. On admission, raised serum heterophilic antibody titres and antibody responses to EBV capsid, both IgG and IgM, were present and persistent for several weeks. No treatment was given and the patient fully recovered in 16 weeks, accompanied by a decline in serum heterophilic antibody titres, and IgM antibodies to EBV capsid antigen.

\section{Discussion}

The immune response in infectious mononucleosis is prompt, and a rise in antibody titre occurs in a small number of cases only, even when serum collection is early in the course of the disease (Joncas, 1972). Antibodies to EBV capsid antigen are not helpful unless titres are very high, and demonstration of EBV-specific IgM is required as evidence of recent EBV infection. Antibodies to EBV capsid antigens have been reported in CSF in patients presenting with cerebellar ataxia (Lascelles et al., 1973), suggesting that this complication is due to EBV involvement of cerebellar tissues, and not due to an allergic or post-infectious phenomenon. The selective appearance of antibody in CSF indicates that viruses other than EBV are not involved. A CSF/serum antibody ratio of $1 / 32$ has 
TABLE 1. Results of Paul Bunnell heterophilic antibodies and Epstein Barr virus (EBV) serological tests

\begin{tabular}{lccccc}
\hline \multicolumn{2}{c}{ Serum heterophilic antibodies titre } & \multicolumn{2}{c}{ Antibody response to EBV capsid antigen } \\
\hline Date & Unabsorbed & $\begin{array}{c}\text { Serum absorbed } \\
\text { with guinea } \\
\text { pig kidney }\end{array}$ & $\begin{array}{c}\text { Serum } \\
\text { absorbed } \\
\text { with ox } \\
\text { cell extract }\end{array}$ & IgG & IgM \\
\hline 19 January 1982 & $1: 448$ & $1: 448$ & $1: 7$ & $1: 64$ & Positive \\
27 January 1982 & $1: 448$ & $1: 448$ & $1: 7$ & $1: 128$ Positive \\
3 February 1982 & $1: 448$ & $1: 448$ & $1: 7$ & $1: 64$ & Weakly positive \\
19 March 1982 & $1: 28$ & $1: 28$ & $1: 7$ & $1: 64$ & Trace \\
7 April 1982 & $1: 7$ & $1: 7$ & $1: 7$ & $1: 64$ & Trace \\
4 May 1982 & $1: 14$ & $1: 14$ & $1: 7$ & $1: 64$ & Negative \\
\hline
\end{tabular}

been reported (Joncas et al., 1974), but the significance of this finding is not yet established. Other central nervous system manifestations associated with infectious mononucleosis include meningitis, encephalitis, transverse myelitis, cranial and peripheral neuropathy, and Guillain-Barré syndrome.

Pathological findings in a fatal case of encephalitis due to infectious mononucleosis include Purkinje cell damage in the cerebellar cortex, with perivascular inflammatory changes, suggesting that EBV directly damages the central nervous system in certain cases (Bergin, 1960).

\section{Acknowledgments}

We are grateful to Mr H. A. Piper at Llanelli General Hospital and to Mr M. Isaac and Miss J. Hunt at the Public Health Laboratory Service, Swansea for their laboratory assistance. We are also grateful to Miss Julie E. Davies for secretarial assistance.

\section{References}

BAJADA, S. (1976) Cerebellitis in glandular fever. Medical Journal of Australia, 1, 153.

BERGIN, J.D. (1960) Fatal encephalopathy in glandular fevesu Journal of Neurology, Neurosurgery and Psychiatry, 23, 69.

Cleary, T.G., Henle, W. \& Pickering, L.K. (1980) Acuta cerebellar ataxia associated with Epstein-Barr virus infection? Journal of the American Medical Association, 243, 148.

Dowling, M.D. \& VANSLYCK, E.J. (1966) Cerebellar disease in infections mononucleosis. Archives of Neurology (Chicago), 15? 270.

JoNCAS, J.H. (1972) Clinical significance of the E. B. herpes virus infection in man. Progress in Medical Virology, 14, 200.

Joncas, J.H., Chicoine, L., Thivierge, R. \& Bertrand, $\mathbf{9}$ (1974) Epstein-Barr virus antibodies in the cerebrospinal fluid. $D$ case of infectious mononucleosis with encephalitis. Amertap Journal of Diseases of Children, 127, 282.

Lascelles, R.G., Longson, M., Johnson, P.J. \& Chiang, A $\overline{\bar{O}}$ (1973) Infectious mononucleosis presenting as acute cerebella syndrome. Lancet, ii, 707.

(Accepted 19 October 1982) 